\title{
Managing Whitefly on Soybean
}

\author{
Jonas A. Arnemann ${ }^{1}$, Henrique Pozebon ${ }^{1}$, Rafael P. Marques ${ }^{1}$, Dener R. Ferreira ${ }^{1}$, Leonardo S. Patias ${ }^{1}$, \\ Júlia G. Bevilaqua ${ }^{1}$, Daniela Moro ${ }^{1}$, Sarah E. Forgiarini ${ }^{1}$, Guilherme Padilha ${ }^{1}$, João V. L. Campos ${ }^{1}$, \\ Jerson V. C. Guedes ${ }^{1}$, Natalie Feltrin ${ }^{1}$, Cristiano de Carli $^{1}$, Glauber R. Sturmer ${ }^{2}$ \& Paulinho E. R. Ferreira ${ }^{3}$ \\ ${ }^{1}$ Departament of Crop Protection, Federal University of Santa Maria, Santa Maria, RS, Brazil \\ 2322 5th Street, Camobi, Santa Maria, RS, Brazil \\ ${ }^{3} 3476$ Pio Menezes Street, Jardim das Oliveiras, Vilhena, RO, Brazil
}

Correspondence: Jonas A. Arnemann, Departament of Crop Protection, Federal University of Santa Maria, Avenida Roraima 1000, Santa Maria, Rio Grande do Sul 97105-900, Brazil. E-mail: jonasarnemann@gmail.com

$\begin{array}{lc}\text { Received: March 13, } 2019 & \text { Accepted: April 21, } 2019 \quad \text { Online Published: June 30, } 2019 \\ \text { doi:10.5539/jas.v11n9p41 } & \text { URL: https://doi.org/10.5539/jas.v11n9p41 }\end{array}$

\begin{abstract}
The whitefly Bemisia tabaci (Gennadius, 1889) is a major pest species in soybean, leading to severe economic losses on this crop due to the difficulties involved on its management. Previously restricted to the Middle-west and Southeast regions of Brazil, whitefly infestations have steadily increased in the Southern state of Rio Grande do Sul, the third biggest soybean growing region of the country. Control failures and scarcity of updated information have led Brazilian soybean growers to raise excessively the number of sprays per crop season, increasing control costs and jeopardizing the long-term sustainbility of this strategy due to selection of resistant strains and potential harmful effects on the environment. The aim of this work was to evaluate the performance of different chemical insecticides in the control of B. tabaci nymphs and adults on soybean crops in two different sites, under the field conditions faced by the growers in the state of Rio Grande do Sul. The most efficient treatment for the control of B. tabaci adults was cyantraniliprole + lambda-cyhalothrin, at the doses of $100+7.5$ g a.i. ha ${ }^{-1}$, which provided $65 \%$ of average control efficiency. As for nymph control, the most efficient treatment was acetamiprid + pyriproxyfen, at the doses of $60+30 \mathrm{~g}$ a.i. ha ${ }^{-1}$, which resulted in $67 \%$ of whitefly control in average. Two sequential sprays beginning at the infestation onset are recommended in order to enhance control efficiency.
\end{abstract}

Keywords: Bemisia tabaci, chemical control, Glycine max, integrated pest management

\section{Introduction}

Soybean (Glycine max) is the main oil-seed crop grown and consumed in the world, with a worldwide production of 336.699 million tons in the 2017/18 cropping season (EMBRAPA, 2018), 35\% of which were grown in Brazil (CONAB, 2018). Alongside Argentina, Paraguay and Bolivia, the total area grown with soybean in South America mounts up to 50 million hectares (FAOSTAT, 2018), most of which are severely attacked by the whitefly Bemisia tabaci (Gennadius, 1889) (Hemiptera: Aleyrodidae). While most pest species are associated with certain growth stages of the soybean plants (e.g., Sternechus subsignatus in the beginning of the cycle, Euchistus heros and other stink bugs during the reproductive phase; see Hoffmann-Cmapo, Silva, \& Oliveira, 1999, and Corrêa-Ferreira \& Panizzi, 1999, respectively), favorable geographic and climatic conditions (e.g., low air humidity and high mean temperatures; Sharma et al., 2013) can allow the occurrence of $B$. tabaci throughout the whole growing cycle of the soybean crop (as reported in Bolivia and the Middle-west region of Brazil), greatly increasing its damage potential and difficulting its control (Lima, Lara, \& Barbosa, 2002).

Soybean plants are directly damaged by whiteflies due to sap sucking and toxin injection, and indirectly by virus transmission and excretion of honeydew, which serves as a substrate for the growth of sooty mold fungi (Hirose et al., 2015). Additionally, B. tabaci has been confirmed as a vector for about ten percent of all known plant pathogenic viruses (Fauquet et al., 2008), and the yield losses resulted from direct and indirect damages on soybean plants can reach up to $300 \mathrm{~kg}$ hectare $\mathrm{e}^{-1}$ (APROSOJA, 2017). Short life cycle (16-25 days; Sottoriva, 2010 ) and high oviposition rates (160 eggs per female; Malumphy, Eyre \& Anderson, 2017) allow B. tabaci to complete 11 to 15 generations per year, with the fast-increasing populations reaching its peak during the flowering stage of the soybean plants (Marabi et al., 2017). Control measures are often compromised due to the 
immobility of whitefly nymphs (Byrne \& Bellows Jr., 1991) and its concentration in the middle and lower thirds of the plant canopy and bottom parts of the leaflets (Pozebon et al., 2019), thus avoinding direct contact with insecticide sprays.

The increasing occurrence of $B$. tabaci on Brazilian soybean fields may be associated with the abusive use of non-selective insecticides and its harmful effects on natural enemies (Vieira et al., 2012), as well as selection pressure on resistant strains of the pest (Silva, Omoto, Bleicher, \& Dourado, 2009). Management programs of whitefly rely heavily on the use of chemical insecticides, due to the absence of alternatives such as biological control agents (e.g., predators and parasitoids) and varietal resistance. Entomopathogenic fungi (e.g., Beauveria bassiana) have been efficiently used in the control of whitefly nymphs (Neto \& Barros, 2016), but the particularities involved in its use allied to the high number of fungicide sprays (usually four to five per crop cycle) prevent a broader adoption of such strategies. As a result, Brazilian soybean growers have reported the use of five to six insecticide sprays aiming specifically at this pest during the crop cycle (APROSOJA, 2017), with the total cost of whitefly control mounting up to U\$ 75.00 hectare $^{-1}$ (EMBRAPA, 2017).

Most researches on B. tabaci control are carried out in the Middle-west (Silva et al., 2003; Garcia et al., 2005; Silva et al., 2012) and Southeast (Alves et al., 2001; Valle, Lourenção, \& Novo, 2002; Bacci et al., 2007) regions of Brazil, whereas whitefly infestations have been steadily increasing in the Southern states (Bernardi, 2016) and demanding up to $67 \%$ of all chemical insecticides sprayed on horticulture crops (Rosa, 2017). Satisfactory control efficiencies $(\geq 80 \%)$ of $B$. tabaci are obtained only with highly specific and costly active ingredients, such as spiromesifene in cotton crops (Netto \& Barros, 2016) and cyantraniliprole + lambda-cyhalothrin in tomato crops (Arnemann et al., 2019). In addition, while some sampling methods have been proposed (Czepak et al., 2018), a standardized method for monitoring and control decision remains absent due to the lack of a defined economic injury level for $B$. tabaci on soybean crops. In this sense, scientific research that supports the definition of efficient whitefly management strategies and ensures that this information is taken to the soybean growers and field professionals in Southern Brazil becomes extremely necessary.

The aim of this work was to evaluate the efficiency of chemical inseticides in the control of B. tabaci adults and nymphs on soybean plants under field conditions, in two different sites, in order to estabilish the most efficient strategy for whitefly control on soybean.

\section{Materials and Methods}

\subsection{Experimental Sites}

The experiments were set in Santa Cruz do Sul, Rio Grande do Sul, Brazil. The climate is classified as Cfa according to Köppen's classification (Köppen, 1948), which is defined as a humid subtropical climate with hot summers. The average temperature is $19.7^{\circ} \mathrm{C}$, with an annual rainfall of $1311 \mathrm{~mm}$. Two areas were chosen as experimental sites in two different commercial soybean fields, where infestation of $B$. tabaci occurred naturally.

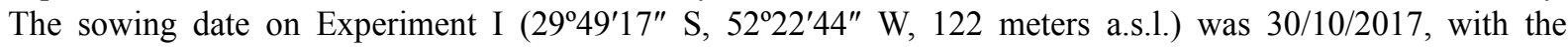
experiment starting in 15/02/2018, when the soybean plants reached growth stage R1 (beginning of the reproductive stage). Whitefly infestation on Experiment I by the time of the first spraying was at a high level (9.68 adults leaflet ${ }^{-1}$ and 1.2 nymphs leaflet ${ }^{-1}$, on average). Sowing on Experiment II $\left(29^{\circ} 43^{\prime} 04^{\prime \prime}\right.$ S, $52^{\circ} 25^{\prime} 33^{\prime \prime}$ W, 122 meters a.s.1.) was carried out in 15/01/2018, with the experiment starting in 14/03/2018, when the soybean plants reached growth stage R1. Infestation level on Experiment II at the moment of the first spraying was moderate to low, with 0.85 adults leaflet $^{-1}$ and 0.7 nymphs leaflet $^{-1}$, on average.

\subsection{Treatments}

The choice of treatments was based on the insecticides commonly used by growers and recommended by field technicians in the region to control B. tabaci on soybean fields. The chemical insecticides composing the treatments, their respective active ingredients, modes of action in the insect's body and spray doses are shown on Table 1. 
Table 1. Active ingredient, mode of action, spray dose and cost hectare ${ }^{-1}$ of the chemical insecticides evaluated for the control of Bemisia tabaci on soybean plants under field conditions. Santa Cruz do Sul, RS, Brazil. 2017/18 cropping season

\begin{tabular}{|c|c|c|c|c|c|}
\hline \multirow{2}{*}{ Treatment } & \multirow{2}{*}{ Active ingredient } & \multirow{2}{*}{ Mode of action } & \multicolumn{2}{|c|}{ Dose ha $^{-1}$} & \multirow{2}{*}{ Cost ha ${ }^{-1}$ (USD) } \\
\hline & & & c.p. ${ }^{1}$ & a.i. $^{2}$ & \\
\hline $\mathrm{T} 1$ & Acetamiprid + pyriproxyfen & $\begin{array}{l}\text { Nicotinic acetylcholine receptor agonists } \\
+ \text { Juvenile hormone mimics }\end{array}$ & 300 & $60+30$ & 30.93 \\
\hline $\mathrm{T} 2$ & Spiromesifene & Inhibitors of acetyl CoA carboxylase & 600 & 144 & 22.42 \\
\hline T3 & Cyantraniliprole & Ryanodine receptor modulators & 1000 & 100 & 90.21 \\
\hline $\mathrm{T} 4$ & Cyantraniliprole + lambda-cyhalothrin & $\begin{array}{l}\text { Ryanodine receptor modulators } \\
+ \text { Sodium channel modulators }\end{array}$ & $1000+30$ & $100+7.5$ & 31.06 \\
\hline T5 & Pymetrozine & Chordotonal organ TRPV channel modulators & 400 & 200 & 46.39 \\
\hline T6 & Imidacloprid + lambda-cyhalothrin & $\begin{array}{l}\text { Nicotinic acetylcholine receptor agonists } \\
+ \text { Sodium channel modulators }\end{array}$ & $300+30$ & $105+7.5$ & 9.39 \\
\hline $\mathrm{T} 7$ & Acetamiprid + bifenthrin & $\begin{array}{l}\text { Nicotinic acetylcholine receptor agonists } \\
+ \text { Sodium channel modulators }\end{array}$ & 160 & $40+40$ & 12.37 \\
\hline $\mathrm{T} 8$ & Cyantraniliprole + abamectin & $\begin{array}{l}\text { Ryanodine receptor modulators + Glutamate-gated } \\
\text { chloride channel }(\mathrm{GluCl}) \text { allosteric modulators }\end{array}$ & 750 & $45+13.5$ & 48.97 \\
\hline T9 & Untreated control & - & - & - & - \\
\hline
\end{tabular}

Note. ${ }^{1}$ c.p. $=$ Commercial product $\left(\mathrm{g}\right.$ or $\mathrm{mL}$ hectare $\left.{ }^{-1}\right) ;{ }^{2}$ a.i. $=$ Active ingredient $\left(\mathrm{g}\right.$ hectare $\left.{ }^{-1}\right)$.

\subsection{Experimental Design}

The experiments were comprised of plots of $24 \mathrm{~m}^{2}(4 \mathrm{~m} \times 6 \mathrm{~m})$, with 4 replicates per treatment, in a randomized block design. Sprayings were carried out using a $\mathrm{CO}_{2}$-pressurized backpack sprayer, nozzles model TJ XR-11002VS, and $150 \mathrm{~L} \mathrm{ha}^{-1}$ of spray volume. Both experiments received two sprays, with an interval of 7 days between them.

\subsection{Evaluations}

Evaluations were made at 0,5 and 10 days after the first spraying (DA1S), and at $0,5,10,15$ and 20 days after the second spraying (DA2S). In each plot, 10 central leaflets were selected from random soybean plants, in the middle and upper thirds. In the abaxial side of these leaflets, the number of whitefly adults was counted in each evaluation, by slowly turning the leaflet upside-down in order to prevent the escape of the insects. To proceed the counting of nymphs, 10 leaflets were collected per plot, from the middle and lower thirds of random soybean plants, stored in separate paper bags and sent for quantification in laboratory with the aid of a Zeiss Discovery.V12 digital magnifying glass.

\subsection{Statistical Analysis}

Control efficiency for each insecticide treatment was assessed through the equation of Abbott (1925), with the obtained values being submitted to variance analysis (ANOVA) and to the mean separation test of Scott-Knott (P $\leq 0.05)$. All statistical analyses were carried out using the softwares Microsoft $\operatorname{Excel}^{\circledR}(2010)$ and $\mathrm{SAS} \circledast(2002)$.

\section{Results and Discussion}

\subsection{Experiment I}

Whitefly population on Experiment I was well estabilished in the soybean field at the moment of the first spray, with an average of 9.68 adults leaflet ${ }^{-1}$ and 1.20 nymphs leaflet $^{-1}$ (Table 2). Despite this condition of high infestation, treatments T4 (cyantraniliprole + lambda-cyhalothrin $100+7.5 \mathrm{~g} \mathrm{ha}^{-1}$ ) and T6 (imidcaloprid + lambda-cyhalothrin $105+7.5 \mathrm{~g} \mathrm{ha}^{-1}$ ) were highly efficient in suppressing adult population at the first evaluation (5 DA1A), reducing it to 1.55 and 2.08 adults leaflet $^{-1}$, respectively. The fast control effect provided by these treatments is probably related to the presence of the active ingredient lambda-cyhalothrin, which is particularly effective in the control of sucking pests (e.g., stink bugs; Marques, 2019) and, as a pyrethroid, is known to cause a fast knockdown effect on the insects due to its mode of action (sodium channel modulator; see Table 1, Salgado, 2013). 
Table 2. Mean number (M) of living adults and nymphs leaflet ${ }^{-1}$ and control efficiency (CE\%) of Bemisia tabaci adults and nymphs in response to the treatments sprayed on soybean plants under field conditions in Experiment I. Santa Cruz do Sul, RS, Brazil

\begin{tabular}{|c|c|c|c|c|c|c|c|c|c|c|c|c|c|}
\hline \multirow{2}{*}{ Treataments } & \multicolumn{2}{|c|}{5 DA1S $^{1}$} & \multicolumn{2}{|c|}{10 DA1S } & \multicolumn{2}{|c|}{5 DA2S } & \multicolumn{2}{|c|}{10 DA2S } & \multicolumn{2}{|c|}{15 DA2S } & \multicolumn{2}{|c|}{20 DA2S } & \multirow{2}{*}{ - Mean CE\% } \\
\hline & $\mathbf{M}^{2}$ & CE\% & M & CE\% & M & $\mathrm{CE} \%$ & M & CE\% & M & CE\% & M & CE\% & \\
\hline \multicolumn{14}{|l|}{ Adults } \\
\hline Acetamiprid + pyriproxyfen & $3.30 \mathrm{~b}$ & 65.89 & $14.18 \mathrm{a}$ & 42.38 & $2.30 \mathrm{a}$ & 47.43 & $4.68 \mathrm{a}$ & 0.00 & $5.58 \mathrm{a}$ & 20.64 & $7.78 \mathrm{a}$ & 0.00 & 29.39 \\
\hline Spiromesifen & $6.00 \mathrm{a}$ & 37.98 & $15.23 \mathrm{a}$ & 38.11 & $1.90 \mathrm{a}$ & 56.57 & $4.88 \mathrm{a}$ & 0.00 & $4.43 \mathrm{a}$ & 37.01 & $5.13 \mathrm{a}$ & 30.03 & 33.28 \\
\hline Cyantraniliprole & $3.88 \mathrm{~b}$ & 59.95 & $15.50 \mathrm{a}$ & 36.99 & $1.80 \mathrm{a}$ & 58.86 & $5.78 \mathrm{a}$ & 0.00 & $4.80 \mathrm{a}$ & 31.67 & $6.78 \mathrm{a}$ & 7.51 & 32.50 \\
\hline Cyantraniliprole + lambda-cyhalothrin & $1.55 \mathrm{~b}$ & 83.98 & $6.29 \mathrm{~b}$ & 74.44 & $0.68 \mathrm{a}$ & 84.57 & $3.70 \mathrm{a}$ & 20.86 & $2.83 \mathrm{a}$ & 59.79 & $4.34 \mathrm{a}$ & 40.78 & 60.74 \\
\hline Pymetrozine & $4.98 \mathrm{~b}$ & 48.58 & $9.50 \mathrm{~b}$ & 61.38 & $2.15 \mathrm{a}$ & 50.86 & $5.33 \mathrm{a}$ & 0.00 & $3.35 \mathrm{a}$ & 52.31 & $4.78 \mathrm{a}$ & 34.81 & 41.32 \\
\hline Imidacloprid + lambda-cyhalothrin & $2.08 \mathrm{~b}$ & 78.55 & $6.03 \mathrm{~b}$ & 75.51 & $1.45 \mathrm{a}$ & 66.86 & $3.78 \mathrm{a}$ & 19.25 & $2.18 \mathrm{a}$ & 69.04 & $4.35 \mathrm{a}$ & 40.61 & 58.30 \\
\hline Acetamiprid + bifenthrin & $3.25 \mathrm{~b}$ & 66.41 & $10.58 \mathrm{~b}$ & 57.01 & $3.40 \mathrm{a}$ & 22.29 & $2.75 \mathrm{a}$ & 41.18 & $2.68 \mathrm{a}$ & 61.92 & $2.75 \mathrm{a}$ & 62.46 & 49.76 \\
\hline Cyantraniliprole + abamectin & $4.93 \mathrm{~b}$ & 49.10 & $14.88 \mathrm{a}$ & 39.53 & $3.63 \mathrm{a}$ & 17.14 & $5.03 \mathrm{a}$ & 0.00 & $4.35 \mathrm{a}$ & 38.08 & $4.75 \mathrm{a}$ & 35.15 & 29.83 \\
\hline Untreated control & $9.68 \mathrm{a}$ & - & $24.60 \mathrm{a}$ & - & $4.38 \mathrm{a}$ & - & $4.68 \mathrm{a}$ & - & $7.03 \mathrm{a}$ & - & $7.33 \mathrm{a}$ & - & - \\
\hline $\mathrm{CV}(\%)^{3}$ & 21.00 & - & 27.62 & - & 31.62 & - & 25.42 & - & 22.6 & - & 27.7 & - & - \\
\hline \multicolumn{14}{|l|}{ Nymphs } \\
\hline Acetamiprid + pyriproxyfen & $0.88 \mathrm{a}$ & 27.08 & $0.23 \mathrm{a}$ & 75.68 & $0.00 \mathrm{a}$ & 100.00 & -4 & -4 & $0.78 \mathrm{a}$ & 78.91 & $0.40 \mathrm{a}$ & 97.71 & 75.88 \\
\hline Spiromesifen & $1.10 \mathrm{a}$ & 8.33 & $2.18 \mathrm{a}$ & 0.00 & $0.13 \mathrm{a}$ & 94.25 & - & - & $0.70 \mathrm{a}$ & 80.95 & $3.70 \mathrm{a}$ & 78.83 & 52.47 \\
\hline Cyantraniliprole & $1.28 \mathrm{a}$ & 0.00 & $0.78 \mathrm{a}$ & 16.22 & $1.93 \mathrm{a}$ & 11.49 & - & - & $1.70 \mathrm{a}$ & 53.74 & $8.50 \mathrm{a}$ & 51.36 & 26.56 \\
\hline Cyantraniliprole + lambda-cyhalothrin & $1.23 \mathrm{a}$ & 0.00 & $0.10 \mathrm{a}$ & 89.19 & $0.40 \mathrm{a}$ & 81.61 & - & - & $0.23 \mathrm{a}$ & 93.88 & $0.33 \mathrm{a}$ & 98.14 & 72.56 \\
\hline Pymetrozine & $1.30 \mathrm{a}$ & 0.00 & $0.30 \mathrm{a}$ & 67.57 & $2.78 \mathrm{a}$ & 0.00 & - & - & $1.65 \mathrm{a}$ & 55.10 & $5.85 \mathrm{a}$ & 66.52 & 37.84 \\
\hline Imidacloprid + lambda-cyhalothrin & $1.33 \mathrm{a}$ & 0.00 & $0.28 \mathrm{a}$ & 70.27 & $1.70 \mathrm{a}$ & 21.84 & - & - & $1.58 \mathrm{a}$ & 57.14 & $1.73 \mathrm{a}$ & 90.13 & 47.88 \\
\hline Acetamiprid + bifenthrin & $0.15 \mathrm{a}$ & 87.50 & $0.58 \mathrm{a}$ & 37.84 & $2.15 \mathrm{a}$ & 1.15 & - & - & $0.75 \mathrm{a}$ & 79.59 & $2.20 \mathrm{a}$ & 87.41 & 58.70 \\
\hline Cyantraniliprole + abamectin & $1.33 \mathrm{a}$ & 0.00 & $0.30 \mathrm{a}$ & 67.57 & $1.08 \mathrm{a}$ & 50.57 & - & - & $0.60 \mathrm{a}$ & 83.67 & $2.18 \mathrm{a}$ & 87.55 & 57.87 \\
\hline Untreated control & $1.20 \mathrm{a}$ & - & $0.93 \mathrm{a}$ & - & $2.18 \mathrm{a}$ & - & - & - & $3.68 \mathrm{a}$ & - & $17.48 \mathrm{a}$ & - & - \\
\hline $\mathrm{CV}(\%)^{3}$ & 26.78 & - & 39.98 & - & 41.01 & - & - & - & 43.5 & - & 66.01 & - & - \\
\hline
\end{tabular}

Note. ${ }^{1} \mathrm{DAS}=$ Days after spraying. ${ }^{2}$ Means followed by the same letter do not differ among themselves by the Scott-Knott test $(\mathrm{P} \leq 0.05) .{ }^{3} \mathrm{CV}(\%)=$ Coefficient of variation. ${ }^{4}$ Lost plot.

The same outcome was verified after the second spray, when treatments $\mathrm{T} 4$ (cyantraniliprole + lambda-cyhalothrin $100+7.5 \mathrm{~g} \mathrm{ha}^{-1}$ ) and T6 (imidcaloprid + lambda-cyhalothrin $105+7.5 \mathrm{~g} \mathrm{ha}^{-1}$ ) kept B. tabaci population under 0.68 and 1.45 adults leaflet ${ }^{-1}$, respectively, and continued to provide the highest contol efficiencies among all treatments (Table 2). On the following evaluations, however, the control efficacy of these treatments steadily descreased, denoting its low potential for residual control; treatment T7 (acetamiprid + bifenthrin $40+40 \mathrm{~g} \mathrm{ha}^{-1}$ ), on the other hand, showed long residual effect, reaching the highest control efficiency among all treatments at 20 DA2A $(62.46 \%)$ and keeping whitefly population under 2.75 adults leaflet ${ }^{-1}$. The presence of the active ingredient acetamiprid in treatment T7 is probably the cause of such outcome, since neonicotinoids are known to provide a long residual control effect (Salgado, 2013).

Treatment T1 (acetamiprid + pyriproxyfen $60+30 \mathrm{~g} \mathrm{ha}^{-1}$ ) was the most efficient treatment in the control of $B$. tabaci nymphs, presenting an average mortality of $75.88 \%$ and nearly totally suppressing its population on the last evaluation ( 0.4 nymphs leaflet $\left.{ }^{-1}\right)$; whitefly adults, however, were poorly controlled by this treatment, reaching an average control efficiency of just $29.39 \%$ (Table 2). Such results, though seemingly contracditory, are expected from treatments containing the active ingredient pyriproxyfen, as showed by Valle, Lourenção, and Novo (2002), and Mesquita, Azevedo, Sobrinho, and Guimarães (2007): both works found pyriproxyfen to be highly efficient in the control of nymphs, partly due to its translaminar action (which enables it to reach the abaxial side of the leaves, where whitefly nymphs are located), but with little to none control effect on whitefly adults.

But how can an insecticide present both the lowest and highest performances on the same pest species, according to the life stage on which it is? The answer is actually quite simple, and is related to the mode of action of pyriproxyfen inside the insect's body. As a substance that mimics the juvenile hormone in order to cause physiological disorder (also known as growth regulator), this insecticide has its action limited to the early stages of the B. tabaci life cycle (see Supplementary Figure 1), since the juvenile hormone plays no major role in the metabolism of the adult (Gallo et al., 2002). Additionally, the other active ingredient composing treatment T1 (acetamiprid $60 \mathrm{~g} \mathrm{ha}^{-1}$ ), though fairly efficient in the control of whitefly adults when associated to the pyrethroid bifenthrin (as in Treatment T7; see Table 2), was not able to keep a high level of adult mortality by its own. 
Similarly to the observed in the adult population, treatment T4 (cyantraniliprole + lambda-cyhalothrin $100+7.5$ $\mathrm{g} \mathrm{ha}^{-1}$ ) showed high efficacy in the control of $\mathrm{B}$. tabaci nymphs, leading to an almost total mortality of individuals at $20 \mathrm{DA} 2 \mathrm{~S}$ (0.33 nymphs leaflet $\left.{ }^{-1}\right)$; however, when used isolated, the insecticide cyantraniliprole (Treatment T3) presented the lowest performance on control of B. tabaci nymphs, providing an average control efficiency of only $26.56 \%$ (against $72.56 \%$ when combined with lambda-cyhalothrin, as in Treatment 4 ; see Table 2). Despite being widely employed to control Hemipteran pests, this anthranilic diamide insecticide has been reported as increasingly inefficient in the control of $B$. tabaci, with field resistance recently confirmed in China (R. Wang, J. Wang, Che, \& Luo, 2018); thus, similar genetic traits in the infesting population surveyed in our work coud be responsible for the lack of control observed for this treatment, though further research would be needed in order to confirm this hypothesis.

\subsection{Experiment II}

B. tabaci population on Experiment II at the spray moment was at a lower level than on Experiment I, with an average of 0.85 adults leaflet $^{-1}$ and 0.7 nymphs leaflet ${ }^{-1}$ (Table 3). As a consequence, the means of control efficiency were overall higher on Experiment II (especially for whitefly adults), although late sowing dates (as carried out on this field) tend to favor whitefly infestation on soybean due to favorable climatic conditions (Marabi et al., 2017) such as higher mean temperatures (see Lapidot, 2007, according to whom adult emergence does not occur below $17{ }^{\circ} \mathrm{C}$ ) and lesser relatively humidity and rainfall (Gupta, Mahapatra, Sanjoy, \& Roshan, 1997) during the soybean growth stage when whitefly infestation reaches its peak (R1 or beginning of reproductive phase; Suekane, Degrande, Melo, Azambuja, \& Menegati, 2018). While there is no defined economic injury level for $B$. tabaci on soybean crops to-date, this results attest the importance of early sprayings at the infestation onset.

Table 3. Mean number (M) of living adults and nymphs leaflet ${ }^{-1}$ and control efficiency (CE\%) of Bemisia tabaci adults and nymphs in response to the treatments sprayed on soybean plants under field conditions in Experiment II. Santa Cruz do Sul, RS, Brazil

\begin{tabular}{|c|c|c|c|c|c|c|c|c|c|c|c|c|c|}
\hline \multirow{2}{*}{ Treataments } & \multicolumn{2}{|c|}{5 DA1S $^{1}$} & \multicolumn{2}{|c|}{10 DA1S } & \multicolumn{2}{|c|}{5 DA2S } & \multicolumn{2}{|c|}{10 DA2S } & \multicolumn{2}{|c|}{15 DA2S } & \multicolumn{2}{|c|}{20 DA2S } & \multirow{2}{*}{ - Mean CE\% } \\
\hline & $\mathbf{M}^{2}$ & CE\% & M & CE\% & $\mathbf{M}$ & CE\% & M & CE\% & $\mathbf{M}$ & CE\% & M & CE\% & \\
\hline \multicolumn{14}{|l|}{ Adults } \\
\hline Acetamiprid + pyriproxyfen & $0.40 \mathrm{a}$ & 52.94 & $0.35 \mathrm{~b}$ & 58.82 & $1.15 \mathrm{a}$ & 42.50 & $0.65 \mathrm{a}$ & 61.76 & $1.43 \mathrm{a}$ & 0.00 & -4 & -4 & 43.20 \\
\hline Spiromesifen & $0.38 \mathrm{a}$ & 55.88 & $0.25 \mathrm{~b}$ & 70.59 & $1.45 \mathrm{a}$ & 27.50 & $1.65 \mathrm{a}$ & 2.94 & $1.08 \mathrm{a}$ & 17.31 & - & - & 34.84 \\
\hline Cyantraniliprole & $0.43 \mathrm{a}$ & 50.00 & $0.23 \mathrm{~b}$ & 73.53 & $0.40 \mathrm{a}$ & 80.00 & $0.80 \mathrm{a}$ & 52.94 & $0.65 \mathrm{a}$ & 50.00 & - & - & 61.29 \\
\hline Cyantraniliprole + lambda-cyhalothrin & $0.23 \mathrm{a}$ & 73.53 & $0.33 \mathrm{~b}$ & 61.76 & $0.28 \mathrm{a}$ & 86.25 & $0.78 \mathrm{a}$ & 54.41 & $0.33 \mathrm{a}$ & 75.00 & - & - & 70.19 \\
\hline Pymetrozine & $0.30 \mathrm{a}$ & 64.71 & $0.25 \mathrm{~b}$ & 70.59 & $1.13 \mathrm{a}$ & 43.75 & $0.65 \mathrm{a}$ & 61.76 & $0.50 \mathrm{a}$ & 61.54 & - & - & 60.47 \\
\hline Imidacloprid + lambda-cyhalothrin & $0.43 \mathrm{a}$ & 50.00 & $0.35 \mathrm{~b}$ & 58.82 & $0.90 \mathrm{a}$ & 55.00 & $0.90 \mathrm{a}$ & 47.06 & $0.65 \mathrm{a}$ & 50.00 & - & - & 52.18 \\
\hline Acetamiprid + bifenthrin & $0.30 \mathrm{a}$ & 64.71 & $0.63 \mathrm{a}$ & 26.47 & $0.53 \mathrm{a}$ & 73.75 & $1.53 \mathrm{a}$ & 10.29 & $1.05 \mathrm{a}$ & 19.23 & - & - & 38.89 \\
\hline Cyantraniliprole + abamectin & $0.50 \mathrm{a}$ & 41.18 & $0.35 \mathrm{~b}$ & 58.82 & $0.98 \mathrm{a}$ & 51.25 & $0.48 \mathrm{a}$ & 72.06 & $0.60 \mathrm{a}$ & 53.85 & - & - & 55.43 \\
\hline Untreated control & $0.85 \mathrm{a}$ & - & $0.85 \mathrm{a}$ & - & $2.00 \mathrm{a}$ & - & $1.70 \mathrm{a}$ & - & $1.30 \mathrm{a}$ & - & - & - & - \\
\hline $\mathrm{CV}(\%)^{3}$ & 29.16 & - & - & - & 24.92 & - & 27.82 & - & 20.59 & - & - & - & - \\
\hline \multicolumn{14}{|l|}{ Nymphs } \\
\hline Acetamiprid + pyriproxyfen & $0.78 \mathrm{a}$ & 0.00 & $1.28 \mathrm{a}$ & 47.42 & -4 & -4 & -4 & -4 & $0.65 \mathrm{~b}$ & 85.87 & $0.00 \mathrm{c}$ & 100.00 & 58.32 \\
\hline Spiromesifen & $0.68 \mathrm{a}$ & 3.57 & $1.88 \mathrm{a}$ & 22.68 & - & - & - & - & $3.38 \mathrm{a}$ & 26.63 & $0.43 \mathrm{c}$ & 73.44 & 31.58 \\
\hline Cyantraniliprole & $1.25 \mathrm{a}$ & 0.00 & $2.23 \mathrm{a}$ & 8.25 & - & - & - & - & $4.15 \mathrm{a}$ & 9.78 & $1.13 \mathrm{~b}$ & 29.69 & 11.93 \\
\hline Cyantraniliprole + lambda-cyhalothrin & $0.90 \mathrm{a}$ & 0.00 & $1.50 \mathrm{a}$ & 38.14 & - & - & - & - & $1.28 \mathrm{~b}$ & 72.28 & $0.78 \mathrm{~b}$ & 51.56 & 40.50 \\
\hline Pymetrozine & $1.60 \mathrm{a}$ & 0.00 & $0.90 \mathrm{a}$ & 62.89 & - & - & - & - & $5.63 \mathrm{a}$ & 0.00 & $3.23 \mathrm{a}$ & 0.00 & 15.72 \\
\hline Imidacloprid + lambda-cyhalothrin & $0.48 \mathrm{a}$ & 32.14 & $1.03 \mathrm{a}$ & 57.73 & - & - & - & - & $4.88 \mathrm{a}$ & 0.00 & $2.88 \mathrm{a}$ & 0.00 & 22.47 \\
\hline Acetamiprid + bifenthrin & $0.58 \mathrm{a}$ & 17.86 & $1.68 \mathrm{a}$ & 30.93 & - & - & - & - & $2.18 \mathrm{~b}$ & 52.72 & $1.28 \mathrm{~b}$ & 20.31 & 30.46 \\
\hline Cyantraniliprole + abamectin & $0.50 \mathrm{a}$ & 28.57 & $1.98 \mathrm{a}$ & 18.56 & - & - & - & - & $2.75 \mathrm{a}$ & 40.22 & $3.35 \mathrm{a}$ & 0.00 & 21.84 \\
\hline Untreated control & $0.70 \mathrm{a}$ & - & $2.43 \mathrm{a}$ & - & - & - & - & - & $4.60 \mathrm{a}$ & - & $1.60 \mathrm{~b}$ & - & - \\
\hline $\mathrm{CV}(\%)^{3}$ & 20.69 & - & 19.74 & - & - & - & - & - & 27.5 & - & 22.91 & - & - \\
\hline
\end{tabular}

Note. ${ }^{1}$ DAS $=$ Days after spraying. ${ }^{2}$ Means followed by the same letter do not differ among themselves by the Scott-Knott test $(\mathrm{P}>0.05) .{ }^{3} \mathrm{CV}(\%)=$ Coefficient of variation. ${ }^{4}$ Lost plot.

Agreeing with the results found on Experiment I, treatment T4 (cyantraniliprole + lambda-cyhalothrin $100+7.5$ $\mathrm{g} \mathrm{ha}^{-1}$ ) presentend the highest average control efficiency $(70 \%)$, keeping the population of whitefly adults at low levels (under 0.78 adults leaflet ${ }^{-1}$ ) in all evaluations. On the other hand, treatment T2 (spiromesifen $144 \mathrm{~g} \mathrm{ha}^{-1}$ ) showed the lowest performance among all treatments, providing only $34.84 \%$ of average adult mortality (Table 
3). Though proved to be very effective against $B$. tabaci populations across the world, this insecticide has been recently linked to field resistance cases in Spain (Bielza, Moreno, Belando, Grávalos, Izquierdo, \& Nauen, 2019), which may be related to the lack of control found in the present study.

Regarding the control of B. tabaci nymphs, treatment T1 (acetamiprid + pyriproxyfen $60+30 \mathrm{~g} \mathrm{ha}^{-1}$ ) continued to provide the highest control efficiencies, reaching $100 \%$ of nymph mortality at 20 DA2S. Conversevely, treatment T3 (cyantraniliprole $100 \mathrm{~g} \mathrm{ha}^{-1}$ ) repeated the poor performance of Experiment I, presenting only $11.93 \%$ of average control efficiency and confirming its low efficacy in the control of nymphs when used isolated. B. tabaci nymph's mortality provided by treatment T5 (pymetrozine $200 \mathrm{~g} \mathrm{ha}^{-1}$ ) was also considerably low, especially on the last evaluations (Table 3); accordingly, resistance to pymetrozine has been reported in field strains of $B$. tabaci, either in specific form or in cross-resistance with neonicotinoids (Gorman et al., 2010).

\subsection{Combined Analysis}

As illustrated in the average means of control efficiency (Table 4), the two experiments agreed on the main outcomes, despite being carried out under different B. tabaci infestation levels. Treatment T4 (cyantraniliprole + lambda-cyhalothrin $100+7.5 \mathrm{~g} \mathrm{ha}^{-1}$ ) led to the highest levels of adult mortality in both experiments, while treatment $\mathrm{T} 1$ (acetamiprid + pyriproxyfen $60+30 \mathrm{~g} \mathrm{ha}^{-1}$ ) performed similarly on whitefly nymphs; nonetheless, given the reasonable nymph reduction provided also by treatment $\mathrm{T} 4$ (see Figure 1), the combination cyantraniliprole + lambda-cyhalothrin $\left(100+7.5 \mathrm{~g} \mathrm{ha}^{-1}\right)$ can be pointed out as the most efficient current alternative for whitefly control on soybean crops, regardless of the infestation level and life phase of the insect. Furthermore, the cost of this treatment (31.06 USD ha ${ }^{-1}$ ) is fairly low when compared to cyantraniliprole $100 \mathrm{~g}$ $\mathrm{ha}^{-1}$ and pymetrozine $200 \mathrm{~g} \mathrm{ha}^{-1}$, for instance (see Table 1); other less-costly treatments, such as imidcaloprid + lambda-cyhalothrin $105+7.5 \mathrm{~g} \mathrm{ha}^{-1}\left(9.39 \mathrm{USD} \mathrm{ha}^{-1}\right)$ and acetamiprid + bifenthrin $40+40 \mathrm{~g} \mathrm{ha}^{-1}$ (12.37 USD $\mathrm{ha}^{-1}$ ), provided adult and nymph mortalities too low to justify its use.

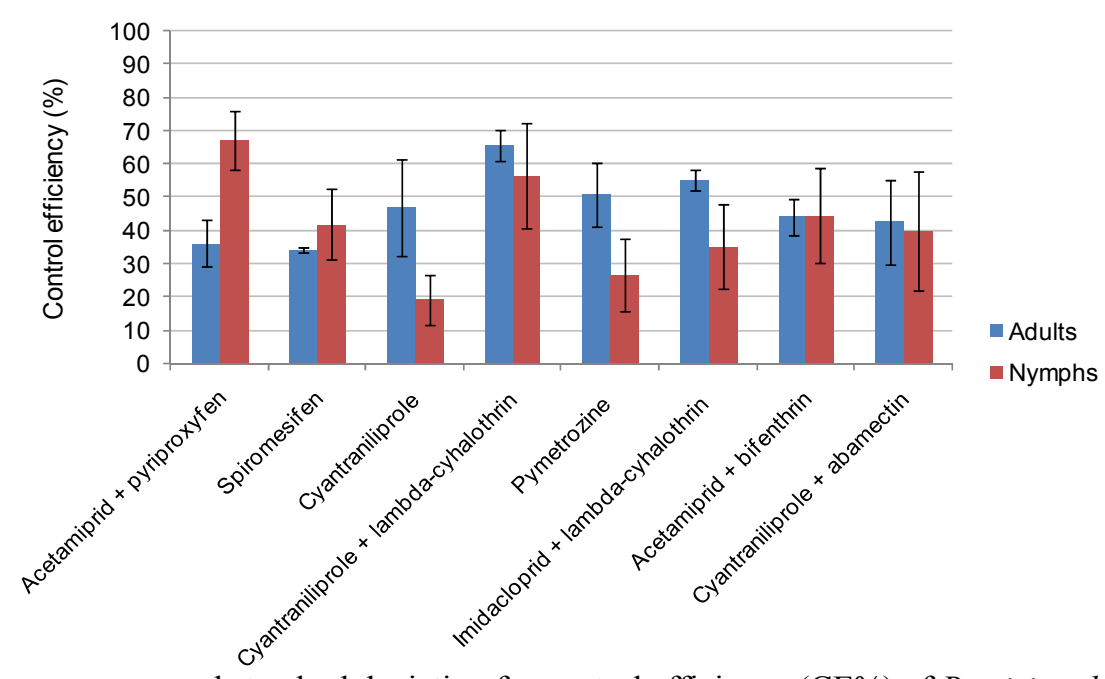

Figure 1. Average means and standard deviation for control efficiency (CE\%) of Bemisia tabaci adults and nymphs in response to the treatments sprayed on soybean plants under field conditions.

Santa Cruz do Sul, RS, Brazil 
Table 4. Means of control efficiency (CE\%) of Bemisia tabaci adults and nymphs in response to the treatments sprayed on soybean plants in Experiment I and Experiment II, under field conditions, and in average means. Santa Cruz do Sul, RS, Brazil

\begin{tabular}{|c|c|c|c|}
\hline Treataments & Experiment I (CE\%) & Experiment II (CE\%) & Average mean (CE\%) \\
\hline \multicolumn{4}{|l|}{ Adults } \\
\hline Acetamiprid + pyriproxyfen & 29.39 & 43.20 & 36.30 \\
\hline Spiromesifen & 33.28 & 34.84 & 34.06 \\
\hline Cyantraniliprole & 32.50 & 61.29 & 46.90 \\
\hline Cyantraniliprole + lambda-cyhalothrin & 60.74 & 70.19 & 65.47 \\
\hline Pymetrozine & 41.32 & 60.47 & 50.90 \\
\hline Imidacloprid + lambda-cyhalothrin & 58.30 & 52.18 & 55.24 \\
\hline Acetamiprid + bifenthrin & 49.76 & 38.89 & 44.33 \\
\hline Cyantraniliprole + abamectin & 29.83 & 55.43 & 42.63 \\
\hline Untreated control & $-\ldots$. & $-\ldots$ & $\therefore \ldots$ \\
\hline \multicolumn{4}{|l|}{ Nymphs } \\
\hline Acetamiprid + pyriproxyfen & 75.88 & 58.32 & 67.10 \\
\hline Spiromesifen & 52.47 & 31.58 & 42.03 \\
\hline Cyantraniliprole & 26.56 & 11.93 & 19.25 \\
\hline Cyantraniliprole + lambda-cyhalothrin & 72.56 & 40.50 & 56.53 \\
\hline Pymetrozine & 37.84 & 15.72 & 26.78 \\
\hline Imidacloprid + lambda-cyhalothrin & 47.88 & 22.47 & 35.18 \\
\hline Acetamiprid + bifenthrin & 58.70 & 30.46 & 44.58 \\
\hline Cyantraniliprole + abamectin & 57.87 & 21.84 & 39.86 \\
\hline Untreated control & - & - & - \\
\hline
\end{tabular}
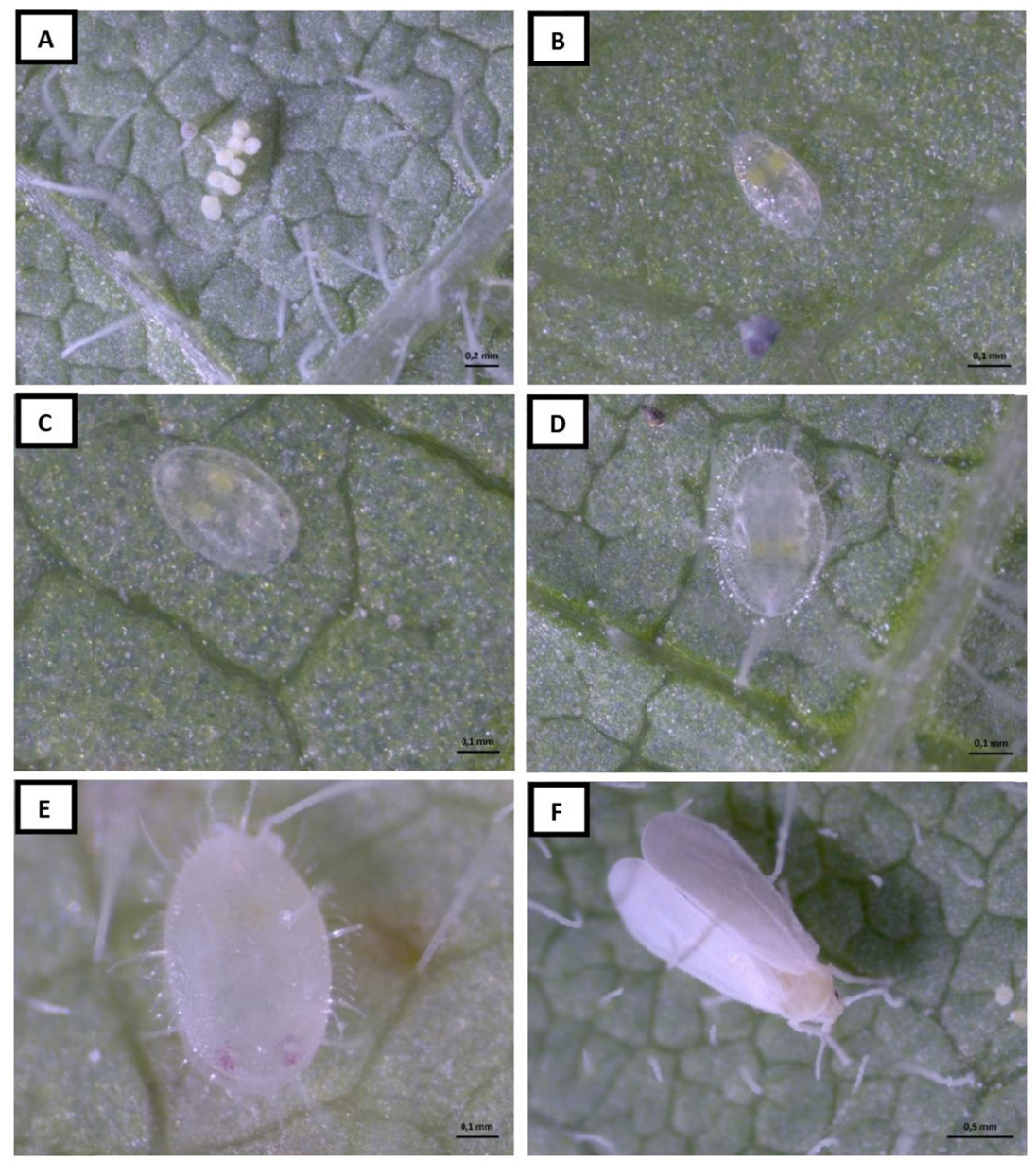

Supplementary Figure 1. Life stages of Bemisia tabaci: A) Egg phase; B) First nymphal phase; C) Second nymphal phase; D) Third nymphal phase; E) Fourth nymphal phase; F) Adult phase. Photos by H. Pozebon 
Nothwithstanding the similarity of results, the overall higher adult mortalities obtained in Experiment II (Table 4) and the enhancement of control efficiency observed after the second spray indicate that sequential sprays beginning at the infestation onset are a key factor for the control of B. tabaci on soybean crops. Accordingly, the threshold for whitefly control on soybean should be set at a very early stage of the infestation, in order to ensure control efficiency and prevent resistance development-which is fast increasing across the world and represents the main likely cause for the lack of control observed in most treatments of the present study, being probably related to enhanced activity of detoxification enzymes and target-site insensitivity in certain $B$. tabaci strains (Zhang, Kong, \& Zeng, 2015). Raising recommended doses to face these problems, though a possible solution for low-performance insecticides, could exceedingly increase control costs with little guarantee of enhanced control efficiency.

Sequential sprays are particularly important for the performance of pyrethroid insecticides, which rely basically on fast knockdown effect (Salgado, 2013); neonicotinoids, on the other hand, provide longer residual effect allied to robust plant sistemicity (Stamm et al., 2016), which may be linked to a higher control efficiency of nymphs, as observed in some of the treatments (e.g., acetamiprid in treatment $\mathrm{T} 1)$. Whitefly nymphs infesting soybean are concentrated in the middle and lower thirds of the plants (Czepack et al., 2018), in the abaxial side of the leaflets and in the middle and bottom areas of its surface (Pozebon et al., 2019), due to the female's habit of feeding and ovipositing in the upper and younger leaves of the soybean plants; therefore, $B$. tabaci adults are more exposed to direct contact with the insecticide spray, while the control of the sheltered nymphs relies more heavily on the efficacy of the insecticide translocation inside the plant.

Pyrethroids as a whole are preferred by the growers due to their fast and visible effect; however, their broad spectrum of action may also result in harmful effects on natural enemies, such as parasitoids (e.g., Encarcia formosa; Vieira et al., 2012) and predators (e.g., Orius tristicolor; Kon, 2016). The active ingredient abamectin (present in treatment T8; see Table 1), on the other hand, has been proved innocuous to whitefly predators (e.g., Lasiochilus sp.; Bacci et al., 2007); the control efficiency provided by this treatment on the present study, however, remained at a low level and do not justify its use. Microbiological insecticides have also been proposed as an alterantive to chemical control, with the fungus Beauveria bassiana being especially efficient in the control of B. tabaci nymphs (Alves et al., 2001; Azevedo, Guimarães, Braga Sobrinho, \& Lima, 2005; Neto \& Barros, 2016); nonetheless, the particularities involved in its use (e.g., slow action, high cost and strong dependence on ideal environmental conditions; Vidal, Fargues, Rougier \& Smits, 2003) prevent a broader adoption of such strategies.

In the current scenario of global agriculture and crop protection, the use of chemical insecticides remains the most efficient and economically viable control strategy for $B$. tabaci on soybean. However, the increasing failures of control and growing occurrence of resistant strains set an alert to the long-term sustaintability of this method, raising the need for new alternative methods inside the integrated pest management (IPM) and integrated resistance management (IRM) approaches for this pest. Accordingly, further studies should be devoted to the establishment of an economic injury level for whitefly on soybean crops, which represents the first step towards a standardized monitoring and control program for any major agricultural pest.

\section{Conclusions}

(1) Cyantraniliprole + lambda-cyhalothrin $\left(100+7.5 \mathrm{~g} \mathrm{ha}^{-1}\right)$ is the most efficient treatment for the control of $B$. tabaci adults, reaching $65 \%$ of control efficiency and keeping the infestation level under 6.29 adults leaflet ${ }^{-1}$;

(2) Acetamiprid + pyriproxyfen $\left(60+30 \mathrm{~g} \mathrm{ha}^{-1}\right)$ is the most efficient treatment for the control of $B$. tabaci nymphs, reaching $67 \%$ of control efficiency and keeping the infestation level under 1.28 nymphs leaflet $^{-1}$;

(3) Sequential sprays beginning at the infestation onset enhance control efficiency.

\section{Acknowledgements}

We thank the soybean growers Marcos Dupont and Heini Cesar Holler for allowing the conduction of this study on their farms.

\section{References}

Alves, S. B., Silveira, C. A., Lopes, R. B., Tamai, M. A., Ramos, E. Q., \& Salvo, S. (2001). Eficácia de Beauveria bassiana, imidacloprid e thiacloprid no controle de Bemisia tabaci e na incidência do BGMV. Manejo Integrado de Plagas, 61, 31-36. 
APROSOJA (Associação dos Produtores de Soja e Milho do Mato Grosso). (2017). Mosca-branca causa perdas nas lavouras de soja no MT. Retrieved from http://ruralcentro.uol.com.br/noticias/mosca-brancacausa-perdas-nas-lavouras-de-soja-no-mt-84060

Arnemann, J. A., Bevilaqua, J. G., Bernardi, L., Rosa, D. O. da, Encarnação, F, A. da, Ribas, D., ... Rohrig, A. (2019). Whitefly on greenhouse tomatoes: Insights on chemical and biological management. Journal of Agricultural Science. https://doi.org/10.5539/jas.v11n5p443

Azevedo, F. R., Guimarães, J. A., Braga Sobrinho, R., \& Lima, M. A. A. (2005). Eficiência de produtos naturais para o controle de Bemisia tabaci Biótipo B (Hemiptera: Aleyrodidae) em meloeiro. Arquivos do Instituto Biológico, 72(1), 73-79.

Bacci, L., Pereira, E. J. G., Crespo, A. L. B., Picanço, M. C., Coutinho, D. C., \& Sena, M. E. (2007). Eficiência e seletividade de inseticidas para o manejo de mosca branca e inimigos naturais em melancia. Ceres, 54(311), 047-054.

Bernardi, L. E. (2016). Bemisia tabaci biótipo A, B, Q? Lageado, RS, Brazil: Emater/RS-ASCAR.

Bielza, P., Moreno, I., Belando, A., Grávalos, C., Izquierdo, J., \& Nauen, R. (2019). Spiromesifen and spirotetramat resistance in field populations of Bemisia tabaci Gennadius in Spain. Pest Management Science, 75, 45-52. https://doi.org/10.1002/ps.5144

Byrne, D. N., \& Bellows Junior, T. S. (1991). Whitefly biology. Annual Review of Entomology, 36, $431-457$. https://doi.org/10.1146/annurev.en.36.010191.002243

CONAB (Companhia Nacional de Abastecimento). (2018). Observatório Agrícola. 2017/2018-Décimo primeiro levantamento. Brasília: Ministério da Agricultura, Pecuária e Abastecimento.

Corrêa-Ferreira, B. S., \& Panizzi, A. R. (1999). Percevejos da soja e seu manejo. Retrieved from https:/www.infoteca.cnptia.embrapa.br/bitstream/doc/461048/1/circTec24.pdf

Czepak, C. (2010). Reação em cadeia. Cultivar Hortaliças e Frutas, 61.

Czepak, C., Coelho, A. S. G., Rezende, J. M., Nunes, M. L. S., Weber, I. D., Silvério, R. F., \& Albernaz-Godinho, K. C. (2018). Bemisia tabaci MEAM1 population surveys in soybean cultivation. Entomologia Experimentalis et Applicata, 166, 215-223. https://doi.org/10.1111/eea.12656

EMBRAPA (Empresa Brasileira de Pesquisa Agropecuária). (2017). Mosca-branca: Infestação baixa e custo alto. Retrieved from https://maissoja.com.br/mosca-branca-infestacao-baixa-e-custo-de-controle-alto

EMBRAPA (Empresa Brasileira de Pesquisa Agropecuária). (2018). Soja em números (Safra 2017/2018). Retrieved from https://www.embrapa.br/soja/cultivos/soja1/dados-economicos

FAOSTAT. (2018). Statistical database. Retrieved from http://faostat.fao.org

Fauquet, C. M., Briddon, R. W., Brown, J. K., Moriones, E., Stanley, J., Zerbini, M., \& Zhou, X. (2008). Geminivirus strain demarcation and nomenclature. Archives of Virology, 153, 783-821. https://doi.org/ 10.1007/s00705-008-0037-6

Gallo, D., Nakano, O., Silveira Neto, S., Carvalho, R. P. L., Batista, G. C., Berti Filho, E., ... Omoto, C. (2002). Entomologia agrícola. Piracicaba, Brazil: FEALQ.

Garcia, R. M., Batista Neto, O. A., De Paula, J. M., Peixoto, M. F., Barros, E. M., \& Jacoby, G. L. (2005). Eficiência de inseticidas químicos no controle de ninfas de mosca-branca Bemisia tabaci (Hemiptera: Aleyrodidae) na cultura do algodoeiro. Salvador, BA, Brazil: V Congresso Brasileiro de Algodão.

Gorman, K., Slater, R., Blande, J. D., Clarke, A., Wren, J., McCaffery, A., \& Denholm, I. (2010). Cross-resistance relationships between neonicotinoids and pymetrozine in Bemisia tabaci (Hemiptera: Aleyrodidae). Pest Management Science, 66(11), 1186-90. https://doi.org/10.1002/ps.1989

Gupta, G. P., Mahapatra, G. K., Sanjoy, K., \& Roshan, L. (1997). Impact of abiotic factors on population of whiterfly in cotton ecosystem symposium on IPM for sustainable crop production held. New Delhi, India: IARI.

Hirose, E., Batista, A. S., \& Silva, M. S. (2015). Correlação da ocorrência de fumagina em soja com a população de ninfas de mosca-branca Bemisia tabaci (Hemiptera: Aleyrodidae). Embrapa Soja, Cuiabá, MT: VI Congresso Brasileiro de Soja. 
Hoffmann-Campo, C. B., Silva, M. T. B., \& Oliveira, L. J. (1999). Aspectos biológicos e manejo integrado de Sternechus subsignatus na cultura da soja. Retrieved from https://www.infoteca.cnptia.embrapa.br/ bitstream/doc/461633/1/circTec22.pdf

Kon, L. I. (2016). Inseticidas eficientes no controle de Bemisia tabaci (Master thesis, Universidade Federal de Viçosa, Minas Gerais, Brazil).

Köppen, W. (1948). Climatologia. México: Fondo de Cultura Economica.

Lapidot, M. (2007). Screening for TYLCV-resistant plants using whitefly mediated inoculation. In H. Czosnek (Ed.), Tomato Yellow Leaf Curl Virus Disease (pp. 329-342). The Netherlands: Springer. https://doi.org/ 10.1007/978-1-4020-4769-5_19

Lima, A. C. S., Lara, F. M., \& Barbosa, J. C. (2002). Oviposition preference of Bemisia tabaci (Genn.) B biotype (Hemiptera: Aleyrodidae) on soybean genotypes, in field conditions. Neotropical Entomology, 31, $297-303$. https://doi.org/10.1590/S1519-566X2002000200018

Malumphy, C., Eyre, D., \& Anderson, H. (2017). Tobacco, sweet potato or silver leaf whitefly: Bemisia tabaci. Retrieved from https://planthealthportal.defra.gov.uk/assets/factsheets/Bemisia-tabaci-Defra-Plant-Pest-Fact sheet-Feb-2017-2.pdf

Marabi, R. S., Das, S. B., Bhowmick, A. K., Pachori, R., \& Sharma, H. L. (2017). Seasonal population dynamics of whitefly (Bemisia tabaci Gennadius) in soybean. Journal of Entomology and Zoology Studies, 5(2), $169-173$

Marques, R. P., Cargnelutti Filho, A., De Carli, C., Rohrig, A., Pozebon, H., Perini, C. R., ... Arnemann, J. A. (2019). Managing stink bugs on soybean fields: Insights on chemical management. Journal of Agricultural Science, 11(6), in press.

Mesquita, A. L. M., Azevedo, F. R., Sobrinho, R. B., \& Guimarães, J. A. (2007) Eficiência do controle químico sobre a mosca branca Bemisia tabaci biótipo B (Hemiptera: Aleyrodidae) em meloeiro. Caatinga, 20(3), 77-84.

Netto, J. C. \& Barros, E. M. (2016). Efeito de inseticidas sobre o controle de mosca-branca na cultura do algodoeiro. Cuiabá, MT, Brazil: Instituto Mato-Grossense do Algodão.

Pozebon, H., Cargnelutti Filho, A., Guedes, J. V. C., Ferreira, D. R., Marques, R. P., Bevilaqua, J. G., ... Arnemann, J. A. (2019). Bemisia tabaci (Gennadius, 1889) on soybean plants: Vertical distribution and on leaflets. Entomologia Experimentalis et Applicata.

Rosa, D. O. (2017). Diagnóstico do uso e do manejo de agrotóxicos na olericultura em propriedades de agricultura familiar no município de Feliz. Universidade Federal de Santa Maria, Santa Maria, Brazil.

Salgado, V. L. (2013). BASF Insecticide Mode of Action Technical Training Manual. Retrieved from https:/www.researchgate.net/publication/275959530_BASF_Insecticide_Mode_of_Action_Technical_Trai ning_Manual

Sharma, D., Maqbool, A., Ahmad, H., Srivastava, K., Kumar, M., \& Jamwal, V. V. S. (2013). Effect of meteorological factors on the population dynamics of insect pests of tomato. Vegetable Science, 40(1), 90-92.

Silva, L. M., Albernaz, K. C., Takatsuta, F. S., Silveira, C., Veloso, G., Fernandes, P. M., \& Czepak, C. (2002). Comparacação da eficiência de inseticidas para controle de Bemisia argentifolii (Hemiptera: Aleyrodidae) na cultura do algodão. Goiânia, GO, Brazil: IV Congresso Brasileiro de Algodão.

Silva, L. D., Omoto, C., Bleicher, E., \& Dourado, P. M. (2009). Monitoramento da suscetibilidade a inseticidas em populações de Bemisia tabaci (Gennadius) (Hemiptera: Aleyrodidae) no Brasil. Neotropical Entomology, 38(1), 116-125. https://doi.org/10.1590/S1519-566X2009000100013

Silva, L. B. G. R. F., Araujo, C. L. P., Silva, S. H., Carvalho, M. M., Siva, A. J., \& Czepak, C. (2012). Eficiência de inseticida para controle de mosca branca na cultura do tomate. XXIV Congresso Brasileiro de Entomologia, Curitiba, PR, Brazil.

Sottoriva, L. D. M. (2010). Aspectos biológicos de Bemisia tabaci biótipo B em plantas infestantes (Master thesis, Instituto Agronômico de Campinas, São Paulo, Brazil). 
Stamm, M. D., Heng-Moss, T. M., Baxendale, F. P., Siegfried, B. D., Blankenship, E. E., \& Nauen, R. (2016). Uptake and translocation of imidacloprid, clothianidin and flupyradifurone in seed-treated soybeans. Pest Management Science, 72, 1099-1109. https://doi.org/10.1002/ps.4152

Suekane, R., Degrande, P. E., Melo, E. P. de, Azambuja, T. M., \& Menegati, C. T. (2018). Spatial distribution of soybean plants infested with whitefly Bemisia tabaci (Gennadius, 1889) (Hemiptera: Aleyrodidae). Arquivos do Instituto. Biológico, 85, 1-6, e0642016. https://doi.org/10.1590/1808-1657000642016

Valle, G. E., Lourenção, A. L., \& Novo, J. P. S. (2002). Controle químico de ovos e ninfas de Bemisia tabaci Biótipo B (Hemiptera: Aleyrodidae). Scientia Agricola, 59(2), 291-294. https://doi.org/10.1590/S010390162002000200013

Vidal, C., Fargues, J., Rougier, M., \& Smits, N. (2003). Effect of air humidity on the infection potential of hyphomycetous fungi as mycoinsecticides for Trialeurodes vaporariorum. Biocontrol Science and Technology, 13, 183-198. https://doi.org/10.1080/0958315021000073457

Vieira, S. S., Boff, M. I. C., Bueno, A. F., Gobbi, A. L., Lobo, R. V., \& Bueno, R. C. O. de F. (2012). Effects of insecticides used in Bemisia tabaci (Gennadius) biotype B control and their selectivity to natural enemies in soybean crop. Ciências Agrárias, 33(5), 1809-1818. https://doi.org/10.5433/1679-0359.2012v33n5p1809

Wang, R., Wang, J., Che, W., \& Luo, C. (2018). First report of field resistance to cyantraniliprole, a new anthranilic diamide insecticide, on Bemisia tabaci MED in China. Journal of Integrative Agriculture, 17(1), 158-163. https://doi.org/10.1016/S2095-3119(16)61613-1

Zhang, B., Kong, F., \& Zeng, X. (2015). Detoxification enzyme activity and gene expression in Diafenthiuron resistant whitefly, Bemisia tabaci. Journal of Agricultural Science, 7(9). https://doi.org/10.5539/ jas.v7n9p66

\section{Copyrights}

Copyright for this article is retained by the author(s), with first publication rights granted to the journal.

This is an open-access article distributed under the terms and conditions of the Creative Commons Attribution license (http://creativecommons.org/licenses/by/4.0/). 